\title{
Effects of Rhizobium, PSB Inoculation and Phosphorus Management on Soil Nutrient Status and Performance of Cowpea in Acid Soil of Arunachal Pradesh, India
}

\author{
Punabati Heisnam $^{1 *}$, Dinesh $\mathrm{Sah}^{2}$, Abhinash Moirangthem ${ }^{3}$, M. ChandraKumar Singh ${ }^{4}$, \\ P.K. Pandey ${ }^{4}$, Nabin Kumar Mahato ${ }^{5}$, Reema Longjam ${ }^{4}$, P. Debnath ${ }^{6}$ and A.K. Pandey ${ }^{7}$ \\ ${ }^{1}$ Teaching Associate (Agronomy); ${ }^{2}$ Assistant Professor (Agronomy); ${ }^{3}$ Ph.D Scholar, U.B.K.V., \\ ${ }^{4}$ FCLA, Basic Science and Humanities; ${ }^{5}$ FCLA, NRM; ${ }^{6}$ Associate Professor (Soil Science); \\ ${ }^{7}$ Dean, CHF, Pasighat; West Bengal, India \\ *Corresponding author
}

\section{A B S T R A C T}

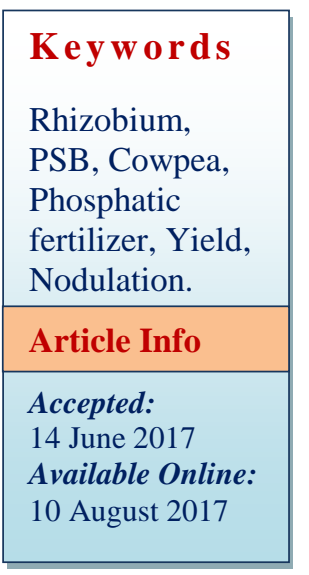

An investigation was carried out to study the effects of Rhizobium, PSB inoculation and phosphorus management on soil nutrient status and performance of cowpea at College of Horticulture and Forestry, CAU, Pasighat during pre-kharif seasons of 2017. The present study shows the effects of Rhizobium, PSB in single and duel combination with or without $\mathrm{P}_{2} \mathrm{O}_{5}$ on cowpea. The results of these experiment reveals that duel inoculation with fertilizer $\left(\mathrm{P}_{2} \mathrm{O}_{5}\right)$ significantly increase plant growth parameters viz. Plant height, number of green leaves, branching, plant biomass, etc., yield attributes, green pod yield, soil available $\mathrm{N}, \mathrm{P}, \mathrm{K}$ status and root nodulation. It is concluded duel inoculation along with $\mathrm{P}_{2} \mathrm{O}_{5}$ fertilizer (PSB + Rhizobium $+40 \mathrm{~kg} \mathrm{P}_{2} \mathrm{O}_{5}$ ) is $34 \%$ better than duel inoculation without phosphatic fertilizer for improving pod yield of cowpea. Application of biofertilizer (PSB and Rhizobium) along with $40 \mathrm{~kg} \mathrm{P}_{2} \mathrm{O}_{5}$ also improves root nodulation and Rhizobium population in soil. It was observed that the nutrient availability to the crop without breaking the sustainability of the soil can be increase only by combined application biofertilizers (PSB and Rhizobium) along with phosphatic fertilizers.

\section{Introduction}

Cowpea [Vigna unguiculata (L.) Walp.] is an important legume vegetable crop as well as pulse grown in India. It is warm season crop of humid tropics and sub tropical zones, well adapted to many areas of the country including North East India. It has manifold uses such as vegetable, pulse, green manuring and fodder crop (Singh et al., 2012). Cowpea leaves and green pods are consumed as vegetable and the dried grain is used in many different food preparations. In India, cowpea is grown on about 0.5 million ha with an average productivity of 600 to $750 \mathrm{~kg}$ grains/ha (Meena et al., 2010). Yield potential of cowpea can be exploited by the application of adequate amount of nutrients required by the legumes.

Generally, Indian soils under natural condition are lacking in effective and specific strain of Rhizobium, which is responsible for symbiotic nitrogen fixation and in turn economic grain yield of pulse (Shaktawat, 1998). Rhizobium inoculation also serves as a 
cheaper and usually more effective agronomic practice for ensuring adequate nitrogen nutrition of legumes than the application of nitrogen fertilizer (Wange, 1989). Studies on inoculation of pulses with PGPR and Rhizobium cause growth stimulation of plant and enhances crop yield (Sharma et al., 2007). The synergism has also been reported between Rhizobium spp. and PSB in urdbean (Prasad et al., 2002). Although pulses are capable of fixing atmospheric nitrogen yet they need a small basal dose of nitrogenous fertilizer for quick and better start. Next to nitrogen, phosphorus is regarded as the pioneer plant nutrient, since it is needed by the leguminous crop for rapid and healthy root development, which becomes helpful in greater nodulation by Rhizobium bacteria (Singh et al., 2007). The report on application of biofertilizers on yield of legumes for soil of North-Eastern hill region, particularly Arunachal Pradesh is very meager. Hence, the present investigation was therefore undertaken to study the effects of Rhizobium, PSB inoculation and phosphorus management in cowpea.

\section{Materials and Methods}

A field study was conducted to assess the response of cowpea on application of Rhizobium and PSB with or without phosphorus at NRM farm $\left(28^{0} 07^{\prime} \mathrm{N}\right.$ latitude and $95^{\circ} 33^{\prime}$ E longitude) of College of Horticulture and Forestry, Central Agricultural University, Pasighat, East Siang, Arunachal Pradesh during pre-kharif cropping season of 2017. The soil of the experimental site was sandy loam with a $\mathrm{pH}$ of 5.2, organic carbon $2.1 \%$ medium in available nitrogen and potassium and high in phosphorus. Seven different nutrients treatments comprising of viz. $\mathrm{T}_{1}$ : $\mathrm{PSB}+$ Rhizobium, $\mathrm{T}_{2}$ : $\mathrm{PSB}+$ Rhizobium+ $20 \mathrm{~kg} \mathrm{P}_{2} \mathrm{O}_{5}, \mathrm{~T}_{3}$ : $\mathrm{PSB}+20 \mathrm{~kg}$ $\mathrm{P}_{2} \mathrm{O}_{5}, \mathrm{~T}_{4}$ : Rhizobium $+20 \mathrm{~kg} \mathrm{P}_{2} \mathrm{O}_{5}, \mathrm{~T}_{5}: \mathrm{PSB}+$ Rhizobium $+40 \mathrm{~kg} \mathrm{P}_{2} \mathrm{O}_{5}, \mathrm{~T}_{6}: \mathrm{PSB}+40 \mathrm{~kg}$
$\mathrm{P}_{2} \mathrm{O}_{5}, \mathrm{~T}_{7}$ : Rhizobium $+40 \mathrm{~kg} \mathrm{P}_{2} \mathrm{O}_{5}$ were evaluated in Randomized Block Design with three replications. Bush type Cowpea variety Kashi Kanchan developed from IIVR, Vanarasi (U.P.) was sown on $8^{\text {th }}$ February, 2017 at $50 \times 20 \mathrm{~cm}$ row to row and plant to plant spacing, respectively, using seed rate 50 $\mathrm{kg} / \mathrm{ha}$. Recommended dose of fertilizers (20 $\mathrm{kg} \mathrm{N}$ and $30 \mathrm{~kg} \mathrm{~K}_{2} \mathrm{O}$ ) was applied as basal application through Urea and MOP in all the plots.

Phosphatic fertilizer (SSP) was applied as recommended. Various weather parameters were recorded during crop growing period. The crop in its life cycle experienced 884.2 $\mathrm{mm}$ rainfall, $4.9 \mathrm{~mm}$ evaporation, relative humidity 65 to $96.3 \%$ and the maximum and minimum temperature in the range of 21.4 to 31.5 and 11 to $19^{\circ} \mathrm{C}$, respectively. The observations on nutrient management for growth parameters and yield attributes were recorded. Pods were harvested from net plot in six pickings. The data on individual plots presents in the experimental field were recorded at 35 DAS, 70 DAS and at harvest by tagging five plants. The soil sample from 0-15 cm depth were taken for chemical analysis after the harvest of the cowpea and soil parameters viz. Organic carbon, Electrical conductivity, Nitrogen, Phosphorus and Potassium status of soil were estimated by standard analytical methods (Jackson, 1973, Tandon, 1999). Rhizobium population count were made from each individual plots using nodulation dilution frequency method (Katura Tuzimura and Iwao Watanade, 1961) and most probable number (MPN) were counted. For recording number of nodules, five plants were randomly selected and removed from each plot at 45 DAS. The standard error of mean (SEm \pm ) and critical difference (CD) values at $\mathrm{p}=0.05$ were used to determine the significance difference between the mean values. 


\section{Results and Discussion}

\section{Effects on crop growth parameters}

The data on crop growth parameters such as plant height, number of leaves, number of branches, LAI, days to flower initiation, days to $50 \%$ flowering are presented in table 1 . Results revealed that the Rhizobium inoculation with phosphorus application enhanced the growth parameters of cowpea. The finding was also validated with result of Singh et al., 2007. Rhizobium inoculation along with application of $40 \mathrm{~kg} \mathrm{P}_{2} \mathrm{O}_{5} / \mathrm{ha}_{\left(\mathrm{T}_{7}\right)}$ significantly increased the plant height, number of leaves, number of branches and LAI which was at par with Rhizobium $+20 \mathrm{~kg}$ $\mathrm{P}_{2} \mathrm{O}_{5}\left(\mathrm{~T}_{4}\right)$ and $\mathrm{PSB}+$ Rhizobium $+40 \mathrm{~kg} \mathrm{P}_{2} \mathrm{O}_{5}$ $\left(\mathrm{T}_{5}\right)$. In case of flower initiation and $50 \%$ flowering, inoculation of Rhizobium with Phosphate solubilising bacteria and phosphatic fertilizer i.e. PSB + Rhizobium + $40 \mathrm{~kg} \mathrm{P}_{2} \mathrm{O}_{5}\left(\mathrm{~T}_{5}\right), \quad \mathrm{PSB}+$ Rhizobium $+20 \mathrm{~kg}$ $\mathrm{P}_{2} \mathrm{O}_{5}\left(\mathrm{~T}_{2}\right)$ and $\mathrm{PSB}+40 \mathrm{~kg} \mathrm{P}_{2} \mathrm{O}_{5}\left(\mathrm{~T}_{6}\right)$ recorded highest values. The treatment using PSB + Rhizobium $\left(\mathrm{T}_{1}\right)$ was found to be inferior for all the growth parameters of cowpea. This was also supported by Singh et al., 2007.

\section{Effects on yield attributes and yield}

Phosphatic fertilizer levels exerted significant effect on yield indices in cowpea. Seed inoculation with Rhizobium or PSB along with phosphatic fertilizer proved superior compared to biofertilizers (Rhizobium and PSB) alone with respect to yield and yield contributing characters. Table 2 shows that combined inoculation of seed with Rhizobium $+40 \mathrm{~kg} \mathrm{P}_{2} \mathrm{O}_{5}\left(\mathrm{~T}_{7}\right)$ recorded highest fresh weight (140 g/plant) and dry weight (28.1 $\mathrm{g} / \mathrm{ha}$ ) of cowpea which was followed by $\mathrm{T}_{4}$ (Rhizobium $+20 \mathrm{~kg} \mathrm{P}_{2} \mathrm{O}_{5}$ ) and $\mathrm{T}_{5}$ (PSB + Rhizobium $+40 \mathrm{~kg} \mathrm{P}_{2} \mathrm{O}_{5}$ ). The highest weight of pods (10 g/plant), number of pods/plant (14.4), pod yield in g/ha (108.1) and pod yield in $\mathrm{q} /$ ha $(78.3)$ were found in the plot treated with $\mathrm{PSB}+$ Rhizobium $+40 \mathrm{~kg} \mathrm{P}_{2} \mathrm{O}_{5}\left(\mathrm{~T}_{5}\right)$ which was at par with $\mathrm{T}_{7}$ and $\mathrm{T}_{2}$. The increase in yield and yield attributes under combined inoculation of seeds (PSB and Rhizobium) with phosphatic fertilizer treatment might be owing to adequate quantities of plant nutrients supplied to the crop during growth period, resulting in favourable increase in growth and development of crop plant which leads towards increase in yield indices (Pandey et al., 2015). Rhizobium inoculation, nitrogen and phosphorus application enhanced grain and straw yield of cowpea which was due to increasing growth and yield attributing characters. These results support the findings of Jain et al., (1993) and Singh et al., (2007).

\section{Effects on soil chemical properties}

Application of Rhizobium $+40 \mathrm{~kg} \mathrm{P}_{2} \mathrm{O}_{5}\left(\mathrm{~T}_{7}\right)$ recorded highest available nitrogen (385.7 $\mathrm{kg} / \mathrm{ha}$ ) and organic carbon content $(3.1 \%)$ of the soil followed by $\mathrm{T}_{4}$ (Rhizobium $+20 \mathrm{~kg}$ $\mathrm{P}_{2} \mathrm{O}_{5}$ ). The available $\mathrm{P}$ and $\mathrm{K}$ were observed to be maximum in a plot treated with PSB + Rhizobium $+40 \mathrm{~kg} \mathrm{P}_{2} \mathrm{O}_{5}\left(\mathrm{~T}_{5}, 95.4 \mathrm{~kg} / \mathrm{ha}\right)$ and Rhizobium + $20 \mathrm{~kg} \mathrm{P}_{2} \mathrm{O}_{5}\left(\mathrm{~T}_{4}, 560.9 \mathrm{~kg} / \mathrm{ha}\right)$, where both was at par with $\mathrm{T}_{7}$ treatment (Rhizobium $+40 \mathrm{~kg} \mathrm{P}_{2} \mathrm{O}_{5}$ ) (Table 3). This may be due to fact that biofertilizers enhanced soil fertility by solubilising unavailable sources of elemental nitrogen, bound phosphorus and non-exchangeable potassium into forms to facilitate the plant to absorb them (Goud and Kale, 2011). Mostly all the plots treated with only biofertilizers (PSB + Rhizobium) was observed to be lowest. In case of soil parameters such as EC and Soil $\mathrm{pH}$ lowest were also estimated under the treatments without phosphatic fertilizer (PSB + Rhizobium) while the other treatments was found to be at par with each other. Pandey et al., (2015) also reported that combined inoculation of Rhizobium, PSB and PGRR improved the nutrient status of soil through 
their synergistic effect on nitrogen fixation and solubilisation of native soil phosphorus which increased availability and uptake of these nutrients by the crop plant (Urd bean) resulted in enhanced yield indices. Higher NPK uptake in combined inoculation of
Rhizobium + PSB + PGRR is due to their additive effects (Prasad et al., 2002). Seed inoculation with biofertilizers reduced the bulk density and enhanced organic carbon and available $\mathrm{N}, \mathrm{P}, \mathrm{K}$ contents of the soil.

Table.1 Effects of Rhizobium and PSB inoculation on the growth parameters

\begin{tabular}{|c|c|c|c|c|c|c|c|c|}
\hline \multirow[b]{2}{*}{ Treatments } & \multicolumn{2}{|c|}{ Plant Height } & \multicolumn{2}{|c|}{ Leaf } & \multirow{2}{*}{$\begin{array}{l}\text { Branch } \\
70 \text { DAS }\end{array}$} & \multirow[b]{2}{*}{ LAI } & \multirow{2}{*}{$\begin{array}{c}\text { Days to } \\
\text { flower } \\
\text { initiation }\end{array}$} & \multirow{2}{*}{$\begin{array}{c}\text { Days to } \\
50 \% \\
\text { flowering }\end{array}$} \\
\hline & $\begin{array}{c}35 \\
\text { DAS }\end{array}$ & $\begin{array}{c}70 \\
\text { DAS }\end{array}$ & $\begin{array}{c}35 \\
\text { DAS }\end{array}$ & $\begin{array}{c}70 \\
\text { DAS }\end{array}$ & & & & \\
\hline T1 PSB + Rhizobium & 17.1 & 90.4 & 8.3 & 94.7 & 2.4 & 17.9 & 65.0 & 71.0 \\
\hline $\begin{array}{l}\text { T2 PSB + Rhizobium+ } \\
20 \text { kg P2O5 }\end{array}$ & 19.1 & 107.1 & 11.0 & 105.4 & 2.4 & 22.0 & 66.3 & 72.3 \\
\hline T3 PSB + 20 kg P2O5 & 17.8 & 106.3 & 10.0 & 95.1 & 3.0 & 19.8 & 65.7 & 72.0 \\
\hline $\begin{array}{l}\text { T4 Rhizobium + } 20 \text { kg } \\
\text { P2O5 }\end{array}$ & 21.4 & 117.2 & 11.7 & 110.7 & 4.0 & 22.7 & 65.3 & 71.3 \\
\hline $\begin{array}{l}\text { T5 PSB + Rhizobium + } \\
40 \mathrm{~kg} \text { P2O5 }\end{array}$ & 20.7 & 107.7 & 11.0 & 108.8 & 4.1 & 22.2 & 66.3 & 72.3 \\
\hline T6 PSB + 40 kg P2O5 & 18.0 & 106.7 & 10.0 & 102.8 & 2.8 & 21.2 & 66.3 & 72.0 \\
\hline $\begin{array}{l}\text { T7 Rhizobium + } 40 \mathrm{~kg} \\
\text { P2O5 }\end{array}$ & 21.6 & 125.5 & 12.4 & 116.1 & 4.3 & 24.4 & 66.0 & 72.0 \\
\hline SEm & 0.62 & 2.36 & 0.62 & 3.61 & 0.18 & 0.95 & 0.29 & 0.40 \\
\hline $\operatorname{CD}(0.05 \%)$ & 1.56 & 5.95 & 1.57 & 9.10 & 0.45 & 2.39 & 0.73 & 1.00 \\
\hline
\end{tabular}

Table.2 Effects of Rhizobium and PSB inoculation yield and yield attributes

\begin{tabular}{|l|c|c|c|c|c|c|c|}
\hline \multicolumn{1}{|c|}{ Treatments } & $\begin{array}{c}\text { Days to } \\
\text { pod } \\
\text { initiation }\end{array}$ & $\begin{array}{l}\text { fresh wt } \\
\text { (g/plant) }\end{array}$ & $\begin{array}{c}\text { Dry wt. } \\
\text { (g/plant) }\end{array}$ & $\begin{array}{l}\text { Pod wt. } \\
\text { (g/pod) }\end{array}$ & $\begin{array}{l}\text { No. of } \\
\text { pods/plant }\end{array}$ & $\begin{array}{c}\text { Pod yield } \\
\text { (g/plant) }\end{array}$ & $\begin{array}{c}\text { Pod yield } \\
(\mathbf{q} / \mathbf{h a})\end{array}$ \\
\hline T1 PSB + Rhizobium & 69.3 & 90.0 & 18.1 & 6.2 & 11.1 & 80.1 & 58.3 \\
\hline $\begin{array}{l}\text { T2 PSB + } \\
\text { Rhizobium+ 20 kg } \\
\text { P2O5 }\end{array}$ & & & & & & & \\
\hline T3 PSB + 20 kg P2O5 & 69.3 & 123.3 & 25.0 & 8.5 & 13.5 & 91.9 & 67.0 \\
\hline $\begin{array}{l}\text { T4 Rhizobium + 20 kg } \\
\text { P2O5 }\end{array}$ & 69.3 & 103.3 & 20.3 & 7.4 & 12.0 & 85.6 & 62.3 \\
\hline $\begin{array}{l}\text { T5 PSB + Rhizobium } \\
\text { + 40 kg P2O5 }\end{array}$ & 70.7 & 136.7 & 27.3 & 8.4 & 13.2 & 87.5 & 62.3 \\
\hline T6 PSB + 40 kg P2O5 & 70.3 & 106.7 & 26.7 & 10.0 & 14.4 & 108.1 & 78.3 \\
\hline $\begin{array}{l}\text { T7 Rhizobium + 40 kg } \\
\text { P2O5 }\end{array}$ & 70.0 & 140.0 & 28.1 & 9.5 & 14.3 & 95.2 & 69.3 \\
\hline SEm & 0.43 & 30.28 & 3.91 & 0.74 & 2.17 & 8.68 & 5.96 \\
\hline CD(0.05\%) & 1.09 & 76.30 & 9.87 & 1.87 & 5.48 & 21.87 & 15.02 \\
\hline
\end{tabular}


Effects on root nodulation and soil microbial properties

The results revealed that seed inoculation with Rhizobium as well as PSB with Phosphatic fertilizers exhibited superior performance. Table 3 shows that plots treated with $\mathrm{PSB}+$ Rhizobium $+40 \mathrm{~kg} \mathrm{P}_{2} \mathrm{O}_{5}\left(\mathrm{~T}_{5}\right)$ recorded highest number of nodules i.e. 22.7 which was at par with treatment PSB + Rhizobium $+20 \mathrm{~kg} \mathrm{P}_{2} \mathrm{O}_{5}\left(\mathrm{~T}_{2}, 19.0\right)$. The Rhizobium population was also recorded higher under treatment $\mathrm{T}_{5}\left(2.5 \mathrm{x} \quad 10^{6}\right)$ followed by $\mathrm{T}_{2}\left(5.4 \times 10^{5}\right)$. Coinoculation of Rhizobium and PSB recorded significantly higher nodule number and its fresh as well as dry weight than Rhizobium and PSB alone. The increase in nodulation might be due to synergistic effect of the two types of microorganisms for biological nitrogen fixation as against their individual application. Results of the similar kind have also been reported by Rudresh et al., (2005). It is also due to the fact that phosphate solubilizing bacteria by virtue of their property of producing organic acids solubilize insoluble or fixed form of phosphorus in the rhizosphere and make it available to the growing plants, which promotes root development in plants (Rao, 1986). In the present study, a significant response of dual inoculation with Rhizobium and PSB was observed with respect to dry weight per plant. Observations of the similar kind have also been recorded by Gupta and Namdeo (2000) and Barea et al., (2005).

In conclusion, based on above results, it can be concluded that combined treatments of $\mathrm{PSB}+$ Rhizobium $+40 \mathrm{~kg} \mathrm{P}_{2} \mathrm{O}_{5}$ is superior over the remaining treatments with respect to growth parameters, yield and yield attributes, soil chemical properties, its nodulation and Rhizobium population in sandy loam soil of Arunachal Pradesh. Thus, Cowpea variety Kashi Kanchan and inoculation of Rhizobium,
PSB along with phosphatic fertilizer may be recommended to realize higher yield of crops in this region.

\section{Acknowledgement}

Financial assistance from the College of Horticulture and Forestry, CAU, Imphal, Manipur for conducting the study is duly acknowledge.

\section{References}

Barea, J.M., Pozo, M. J., Azcón, R. and Azcón-Aguilar C. 2005. Microbial cooperation in the rhizosphere. $J$. Experimental Bot., 56(417): 1761-1778.

Goud, V.V. and Kale, H.B. 2010. Productivity and profitability of pigeon pea under different sources of nutrients in rainfed condition of Central India. J. Food Legumes, 23(3 and 4): 212-17.

Gupta, S.C. and Namdeo, S.L. 2000. Fertilizer economy through composts and biofertilizer in chickpea. Annals of Plant and Soil Res., 2: 244-246.

Jackson, M.L. 1973. Soil Chemical Analysis. Prentice Hall of India Pvt. Ltd, New Delhi, India.

Jain, P.C., Amar, Chandra, Naidu, A.K., Tiwari, J.P. and Chandra, A. 1993. Influence of nitrogen and NAA on growth and yield parameters of cowpea [Vigna unguiculata (L.) Walp.]. Jawaharlal Nehru Krishi Vishwa vidyalaya Res. J., 27: 49-62.

Katura Tuzimura and Iwao Watanade. 1961. Estimation of number of root nodules bacteria by a nodulation dilution frequency method. Soil Sci. Plant Nutrition, 7(2).

Meena, V., Menon, D. Bhaskar, Reddy, P.P. and Jayasree, K. 2010. Seed production in vegetable cowpea [Vigna unguiculata (L.) Walp] under integrated nutrient management. Legumes Res., 33(4): 299- 
301.

Pandey, I.B., Pandey, R.K. and Rakesh Kumar. 2015. Integrated nutrient management for enhancing productivity and profitability of long duration pigeon-pea (Cajanus cajan) under rainfed condition. Indian J. Agron., 60(3): 436-442.

Prasad, H., Chandra, R., Pareek, R.P. and Kumar N. 2002. Synergism among phosphate solubilizing bacteria, rhizo bacteria and Rhizobium with urdbean. Indian J. Pulse Res., 15(2): 131-135.

Rao Subba, N.S. 1986. Soil Microorganisms and Plant Growth, Oxford and IBH Pub. Co. Pvt. Ltd, New Delhi, India,

Rudresh, D.L., Shivaprakash, M.K., and Prasad, R.D. 2005. Effect of combined application of Rhizobium, phosphate solubilizing bacterium and Trichoderma spp. on growth, nutrient uptake and yield of chickpea (Cicer arietinum L. Appl. Soil Ecol., 28(2): 139-146.

Shaktawat, M.S. 1998. Response of cowpea to phosphorus and Rhizobium inoculation. Indian J. Agron., 33: 34142.

Sharma, K., Dak, G., Agarwal, A., Bhatnagar,
M., and Sharma, R. 2007. Effect of Phosphate solubilising bacteria on the germination of Cicer arietinum seeds and seedling growth. J. Herbal Med. Toxicol., 1(1): 61-63.

Singh, A.K., Bhatt, B.P., Sundaram, P.K., Kumar, S., Bharati, R.C., Chandra, N and Rai, M. 2012. Study of site specific nutrient management of cowpea seed production and their effect on soil nutrient. J. Agri. Sci., 4: 191-198

Singh, A.K., Tripathi, P.N. and Room Singh (2007. Effect of Rhizobium inoculation, nitrogen and phosphorus levels on growth, yield and quality of kharif cowpea [Vigna unguiculata (L.) Walp.]. Crop Res., 33(1, 2 \& 3): 71-73

Tandon, H.L.S. 1999. Methods of Analysis of Soil, Plants, Waters and Fertilizers. Fertiliser Development and Consultation Organization, New Delhi, India.

Wange, S.S. 1989. Response of groundnut (Arachis hypogaea L.) to inoculation with strains isolated from wild arboreal legumes. J. Appl. Microbiol. Biotechnol., 5: 135-141.

\section{How to cite this article:}

Punabati Heisnam, Dinesh Sah, Abhinash Moirangthem, M. ChandraKumar Singh, P.K. Pandey, Nabin Kumar Mahato, Reema Longjam, P. Debnath and Pandey, A.K. 2017. Effects of Rhizobium, PSB Inoculation and Phosphorus Management on Soil Nutrient Status and Performance of Cowpea in Acid Soil of Arunachal Pradesh. Int.J.Curr.Microbiol.App.Sci. 6(8): 937-942. doi: https://doi.org/10.20546/ijcmas.2017.608.115 